\title{
The paleolimnological development of the twin lakes Etujärvi and Takajärvi in Askola, southern Finland - implications for lake management
}

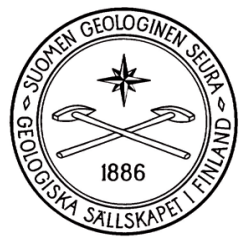

\author{
Samu E. Valpola ${ }^{1) *} \&$ Veli-Pekka Salonen ${ }^{2)}$ \\ 1) Geological Survey of Finland, P.O. Box 97, FI-67101 Kokkola, Finland \\ 2) Department of Geology, P.O. Box 64, FI-00014 University of Helsinki, Finland
}

\begin{abstract}
The twin lakes Etujärvi and Takajärvi in Askola, southern Finland, are closely interconnected mesotrophic headwater lakes with a relatively small catchment area. Both of the lakes have suffered from eutrophication and its consequences. Remediation activities such as oxygenation and biomanipulation have not resolved the problems. In this study a large set of paleolimnological techniques (radiometric AMS dating, spherical carbonaceous particles analysis, sediment lithology, grain-size analysis, phosphorus fractionation, and diatom analysis) were applied to put together the development of the basin and its water level fluctuations during the Holocene. The age for observed Trapa natans -horizons was determined, and lake management options were discussed.

The studied lakes dried up after isolation from the Ancylus Lake at about 9500 cal. B.P. and remained at very low water level until ca. 8700-8500 cal. B.P. The mid-Holocene rise in water level resulted in fluctuating water levels, and led to the most recent rise starting about 2500 cal. B.P. as wet and cool climate conditions prevailed. The pronounced water level fluctuations led to the extensive growth of peat deposits surrounding the lake and probably also forced T. natans to disappear from lake flora. The unstable, erodable peat rims impact the lakes, causing heavy load of humic substances to the lake and presenting additional deterioration to their recreational value.
\end{abstract}

Key words: paleolimnology, lakes, lake sediments, lake-level changes, Trapa natans, water quality, eutrophication, peat, remediation, Holocene, Askola, Finland

*Corresponding author e-mail: samu.valpola@gtk.fi 


\section{Introduction}

Lakes in low-relief glaciated terrain like in Finland have usually been isolated from larger lake basins or from the sea by isostatic land uplift. The isolation horizon can be identified by studying indicator microfossils or by observing the litofacies change in sediment profiles. The sediment deposited in a large water body consists usually of clay, silt or clay/silt gyttja, while the sediment of lake is typically gyttja (Sauramo, 1958).

The lake isolation process is not always straightforward. For example, isolation of a lake basin in a lagoonal environment may be slow and gradational (Eronen, 1974). Secondly, small closed basins might have closed up totally and developed into a bog. About $10 \%$ of peat bogs in Finland have arisen this way (Lappalainen \& Hänninen, 1993). Sometimes, a complicated situation occurs when there is a significant fluctuation in lake water level during and after the isolation from a larger water body (Hyvärinen \& Alhonen, 1994; Harrison et al., 1996; Sarmaja-Korjonen, 2001). Strong lake level fluctuations are often reflected in lithostratigraphy as alternating layers of peat and gyttja (e.g. Dalrymple \& Carey, 1990; Almquist-Jacobson, 1995).

The threshold of studied basin is ca. 40 metres above the present sea level ( $\mathrm{m}$ a.s.l.) indicating that the lakes were isolated from the Ancylus Lake at about 9500 cal. B.P. (Hyvärinen, 1999). In connection with sediment mapping performed for lake restoration purposes an exceptional sediment lithostratigraphy was discovered, a thick layer of peat underlies lacustrine gyttja layers, and in places the clay surface below the peat bear indications of soil formation. It was evident that studied basin had experienced very low water level soon after the isolation.

In addition, continuous layers of seeds of water chestnut (Trapa natans) were found in the course of coring. At the moment there are about 70 localities in Finland, where occurrences of T. natans have been found (Sauramo, 1929; Lumiala, 1943; Valovirta 1949, 1957, 1960; Erkamo \& Backman, 1960; Alhonen 1964, 1996; Eriksson, 1966; Vuorela \& Aal- to, 1982; Korhola \& Tikkanen, 1997; Lempiäinen, 2002). Most of the discoveries of water chestnut are from the southwestern part of the country, with a few occasional finds from central and eastern Finland. The plant has long been connected to the dwelling sites of Stone Age man, "who might have facilitated its subsistence"(Sauramo, 1929).

This study has three interconnected purposes. First, we aim to unravel the apparently complex development of the basins and to shed light on the water level fluctuations during the Holocene. The second target is to give a precise age for the horizon where T. natans is abundant. Thirdly, the importance of the understanding of the lake history for its management purposes will be discussed. Closely related to this, the recent eutrophication development of the lakes was studied from short cores.

\section{Description of the lakes}

The twin headwater lakes Etujärvi and Takajärvi are located on the north side of Askola village, southern Finland (Fig. 1). The catchment area of Lake Etujärvi is $3.52 \mathrm{~km}^{2}$ and that of Lake Takajärvi $2.46 \mathrm{~km}^{2}$. The lakes are mesotrophic, small and shallow, the area of Lake Etujärvi being 16 hectares and the maximum depth approximately $5 \mathrm{~m}$, whereas the area of Lake Takajärvi is 15 hectares and the maximum depth approximately $4 \mathrm{~m}$ (Lempinen et al., 2002). Only a narrow peat covered isthmus separates the lakes from each other. This isthmus formed at the end of the $19^{\text {th }}$ century when the predecessor of the lakes, known as Lake Nalkkilanjärvi, was artificially lowered ca. 1$2 \mathrm{~m}$, leading to the separation of lakes Etujärvi and Takajärvi (Anttila, 1967). The present water level of the lakes is $38.60 \mathrm{~m}$ a.s.l.

The lakes are located within the hemiborealic vegetation zone. The annual mean temperature is ca. + $5^{\circ} \mathrm{C}$, and precipitation over $650 \mathrm{~mm} \mathrm{a}^{-1}$ (Alalammi, 1987). Both of the lakes have suffered from eutrophication and its consequences, such as abundant occurrences of Gonyostomum semen, lack of oxygen and diminution of the Secchi-depth (Lempinen et al., 2002; Reunanen, 2003). During the 2000's the total 

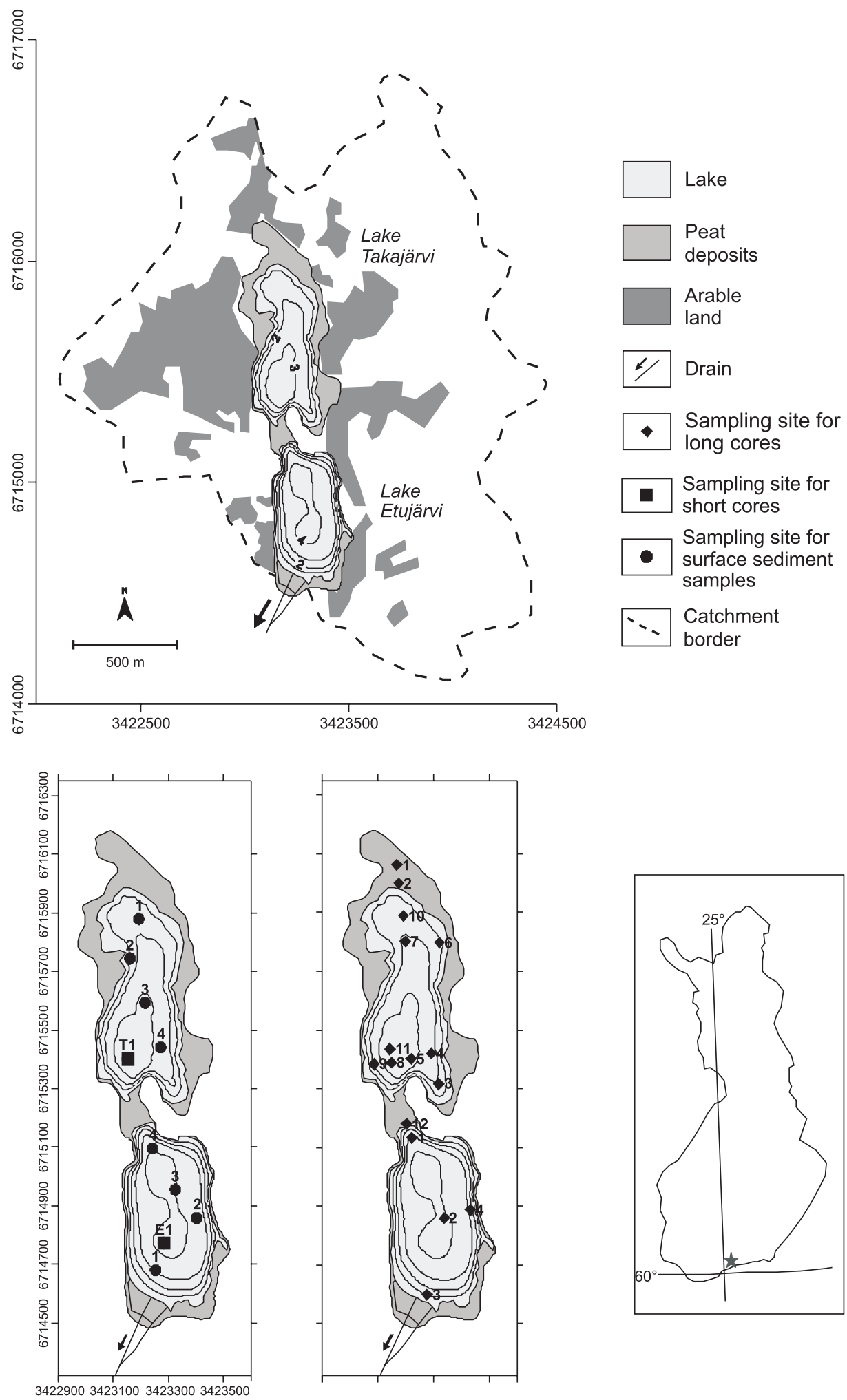

Fig. I. Location map, catchment area, bathymetry (in $\mathrm{m}$ ), position of long-cores, studied short-cores and surface sediment sampling sites of lakes Takajärvi and Etujärvi. Coordinates are according to the Finnish national grid. 
phosphorus content in surface water both in Etujärvi and Takajärvi has been approximately 30-50 $\mathrm{g} \mathrm{l}^{-1}$, total nitrogen approximately $600-800 \mu \mathrm{g} \mathrm{l}^{-1}$, chlorophyll a $40-45 \mu_{\mathrm{g}} \mathrm{l}^{-1}$ and $\mathrm{pH}$ 6.5-7 (HERTTA, 2005). The diffuse nutrient load to the lakes derives from agriculture, forestry and scattered settlements (Reunanen, 2003).

The lakes were a part of a provincial biomanipulation project of eutrophied lakes during 19982001 and the total catch of devaluated fish during the project was $289 \mathrm{~kg} \mathrm{ha}^{-1}$ in Lake Etujärvi and 282 $\mathrm{kg} \mathrm{ha}^{-1}$ in Lake Takajärvi, which has been found to be insufficient (Lempinen et al., 2002). Results of the biomanipulation project have been thoroughly evaluated by Olin (2005) and Olin et al. (in press). The lakes were also oxygenated during the project, but significant improvement in the water quality or the condition of the lakes was not achieved.

The Precambrian bedrock of the area is in general characterized by granodiorite on the east and north sides of the lakes. The western side of the lakes is amfibolite which also occurs within a small area on the east side of Lake Etujärvi. The south-western corner of Lake Etujärvi is abutted by granite with observable mylonite or fault breccias (Laitakari \& Simonen, 1962). The lakes are formed in a long, north-south orientated fault zone, which ranges from the village of Pukkila to the south side of the village of Askola (Laitakari \& Simonen, 1963).

The north-south orientated esker system accumulated in the fracture zone mentioned above is the most important Quaternary deposit of the catchment area of the lakes. It is a discontinuous chain of delta-like deposits, kame-mounds and littoral accumulations. The lakes themselves are surrounded by thick and unstable, easy erodable peat rim. Clay and silt plains are common on the west and south-west side of the lakes. Bedrock outcrops are abundant on the outer limit of the catchment area, both on the west and on the east side of the lakes. By contrast, till deposits are rare, occurring mainly on the eastern side of the catchment area (Tynni \& Kukkonen, 1968; Tynni et al., 1976).

\section{Material and methods}

\section{I. Sampling}

During winter 2004 four surface sediment samples $(0-2 \mathrm{~cm})$ and one short-core profile $(20 \mathrm{~cm})$ were taken using a Limnos gravity-corer (Kansanen et al., 1991) both from Lake Etujärvi and Lake Takajärvi (see Fig. 1). The short-cores were subsampled in 2 $\mathrm{cm}$ slices and stored in a refrigerator at a temperature of $+4^{\circ} \mathrm{C}$. The cores and surface sediment samples were analyzed for their phosphorus content, physical properties such as water content (W), loss on ignition (LOI), the grain size of the mineral matter and, for the short-cores only, the species variability of the diatoms. All the sample points were selected with the aid of map interpretation and using the bathymetric map of lakes Etujärvi and Takajärvi.

According to this preliminary sampling, altogether 16 long-cores were lifted for stratigraphic analysis with a Russian peat corer and, in addition, for the sample point Taka10, with a light piston corer. The long sediment profiles were then characterized applying the classical Troels-Smith method (Troels-Smith, 1955). The core from Taka10 was analyzed for magnetic susceptibility (MS) and LOI.

\subsection{Analytical methods}

Water content of sediment (W) and loss on ignition (LOI) of surface sediment samples, short-core samples, and LOI and magnetic susceptibility (MS) of core Taka10 were determined according to Håkanson \& Jansson (1983) and Boyle (2004). The grain size distribution of sediment samples was analyzed with a Coulter LS 200 laser diffraction analyzer (Agrawal et al., 1991; Arnaud, 2005). Before analysis, organic matter was digested from samples with $\mathrm{H}_{2} \mathrm{O}_{2}$. Samples were then washed three times and $0.05 \mathrm{M} \mathrm{Na}_{4} \mathrm{P}_{2} \mathrm{O}_{7}{ }^{*} 10 \mathrm{H}_{2} \mathrm{O}$ was added to the sample tubes. After that, samples were treated with Sanyo Soniprep 150 ultrasonicator.

Total phosphorus content was analyzed according to Bengtsson \& Enell (1986) and the fractionation of phosphorus according to Hieltjes \& Lijklema (1980). Refractory phosphorus was then calculated 
by subtracting the sum of different fractions from total phosphorus. Determinations of phosphorus were carried out spectrophotometrically applying the molybdenum blue method of Murphy \& Riley (1962). Diatom analyses were carried out from the both short cores. Samples were treated with $\mathrm{H}_{2} \mathrm{O}_{2}$, and then washed four times. A few drops of siliceous slurry were dried on a coverslip, which was fixed on the object glass with Naphrax ${ }^{\circledR}$. At least 300 valves were counted on each slide using an Olympus BX 41 light microscope with $100 x$ plan oil immersion objective, N.A. 1.20, and 10x eyepieces. Krammer \& LangeBertalot (1986-1991a,b) was used as a reference.

The results of diatom analysis were used to reconstruct the development of autumnal surface water total phosphorus concentrations, hereafter DITP. Reconstructions were done by Dr. T. Kauppila according to Kauppila et al. (2002a). The models presented in this paper are weighted average (WA) transfer functions without tolerance downweighting; classical deshrinking is used.

Spherical carbonaceous particles (SCP) were extracted after Rose (1990) and counted with an Olympus CX 31 light microscope (400 x magnification). From each sample at least 250 Lycopodium spores were counted. Results of the counting were then compared with the data of annual fossil fuel combustion in Finland (Statistics Finland, 2003).

Accelerating mass spectrometry (AMS) radiocarbon dating was done on three samples. Samples were treated in the Dating Laboratory of the Finnish Museum of Natural History according to Slota et al. (1987) and then dated in the Uppsala Tandem Laboratory (Possnert, 1984, 1990). Received radiocarbon ages were then calibrated using the $\mathrm{CalPal}^{\odot}$ program and the CalPal_SFCP_2005 calibration curve (Weninger \& Jöris, 2004).

\section{Results}

\section{I. Long cores}

\section{I. I. Sediment lithostratigraphy}

The sediment lithostratigraphy of the long-core samples is described in detail in Fig. 2.
The basal portion of the core Takal is clay. From the level $36.53 \mathrm{~m}$ a.s.l. there follows a 10 -cm-thick transition zone of clay-gyttja, which is overlain by a 207-cm-thick peat sequence extending to the water surface level $38.60 \mathrm{~m}$ a.s.l.

In the core Taka2 the lowermost sampled level (32.60-32.80 $\mathrm{m}$ a.s.l) is gyttja. It is overlain by a 5.8metre-thick peat sequence extending to the water surface level $38.60 \mathrm{~m}$ a.s.l.

The core Taka10 is the only core in the northern part of Lake Takajärvi in which the surface sediment is gyttja. At other coring points from that area the surface sediment is peat. The bottom of the core taken from the coring-point Taka10 is clay, which then changes to silty clay at the level of $30.55 \mathrm{~m}$ a.s.l. This silty clay continues to the level of $31.35 \mathrm{~m}$ a.s.l. In the gyttja section (31.35-32.62 $\mathrm{m}$ a.s.l) there are two horizons rich in Trapa natans remains (Fig. 2). Above this gyttja, in the portion between 32.62 and $32.65 \mathrm{~m}$ a.s.l. there exists a thin layer of clay-gyttja, which changes over sharply to peat. This peat section is the thickest unit of the core, covering the section from 32.65 to $36.60 \mathrm{~m}$ a.s.l. On top of the peat unit there is a thin layer of gyttja (36.60-36.80 $\mathrm{m}$ a.s.l.) and an interlayer of peat (36.80-36.95 $\mathrm{m}$ a.s.l.). The topmost $35-\mathrm{cm}$-thick unit at the sediment surface (36.95-37.30 $\mathrm{m}$ a.s.1.) is gyttja.

Cores Taka 6 and Taka 7 were composed of peat through the recovered sections.

The surface sediment is gyttja in each profile taken from the southern, nowadays deepest, part of Lake Takajärvi (Taka3, Taka4, Taka5, Taka8 and Taka9). The lowermost unit in the cores is clay. This clay changes directly to peat at level $35.10 \mathrm{~m}$ a.s.l. (Taka4) and $33.80 \mathrm{~m}$ a.s.l. (Taka5) whereas in cores Taka8, Taka9 and Taka3 the clay changes first to silty clay and then to peat at levels $34.11 \mathrm{~m}$ a.s.l. (Taka8), $34.62 \mathrm{~m}$ a.s.l. (Taka9) and $35.20 \mathrm{~m}$ a.s.l (Taka10).

In the cores Taka4 and Taka5 there exists a layer of clay-gyttja between gyttja at levels 35.47-35.57 $\mathrm{m}$ a.s.l. (core Taka4) and 34.65-34.95 m a.s.l. (core Taka5).

Cores taken from Lake Etujärvi, (Etu1, Etu2, Etu3, Etu4), from the isthmus between the lakes 


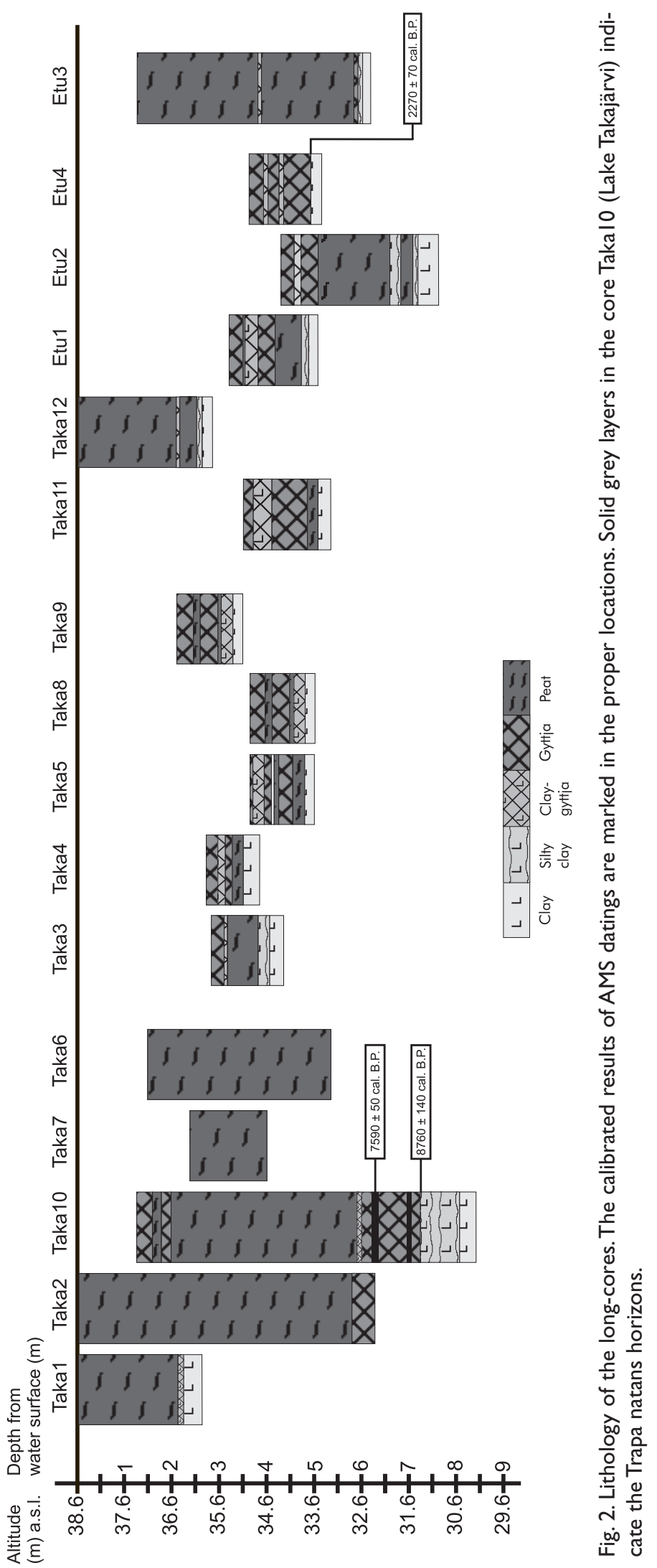


(Taka12) and a comparison sample from Lake Takajärvi (Taka11) are presented in Fig. 2. The bottom of the core Taka12 is clay, which changes to silty clay at the level of $36.12 \mathrm{~m}$ a.s.l. and then to peat at $36.17 \mathrm{~m}$ a.s.l. A thin layer of gyttja exists at level 36.50-36.55 $\mathrm{m}$ a.s.l. and above this gyttja peat continues to the sediment surface (38.60 m a.s.l.).

Core Taka11 compares well with the core Taka5 and the core Etu1 as well. The bottom of the core is clay; the unit above 33.51-33.85 m a.s.l. consists of peat. This peat changes over to gyttja, which is intersected with a 40 -cm-thick unit of clay-gyttja between the levels 34.50-34.90 $\mathrm{m}$ a.s.l. Above this unit the gyttja continues to the sediment surface at 35.10 $\mathrm{m}$ a.s.l.

The lithostratigraphy of core Etu1 matches to Taka11. However, differing from Taka 11, there is a silty clay (33.65-33.81 $\mathrm{m}$ a.s.l.) above the clay and a thin peat layer (35.07-35.10 m a.s.l.) above the claygyttja layer.

Core Etu2 was taken from the deepest point of Lake Etujärvi, where the present water depth is approximately $4.3 \mathrm{~m}$. The bottom of the core is clay. It changes gradually to silty clay, which at the level of $31.47 \mathrm{~m}$ a.s.l. turns to peat. The peat is intersected by a silty clay layer (31.76-31.95 m a.s.l.) and continues upwards to the level of $33.50 \mathrm{~m}$ a.s.l. Above this, there exists a unit of gyttja (33.50-33.85 m a.s.l.) and a layer of clay-gyttja (33.85-33.96 m a.s.l.). The unit from the level of $33.96 \mathrm{~m}$ a.s.l. to the sediment surface (34.30 m a.s.l.) is gyttja.

The core Etu 4 is the only core in this study that does not contain any visible traces of peat. The bottom of the core is clay, which changes to gyttja at the level of $33.72 \mathrm{~m}$ a.s.l. This gyttja section continues to the sediment surface $(35.00 \mathrm{~m}$ a.s.l.) and is intersected by two clay-gyttja layers at levels of 34.30-34.40 and 34.60-34.70 $\mathrm{m}$ a.s.l.

The core taken from sample point Etu3 is mainly peat. The bottom clay of the core changes gradually to silty clay, which has a sharp contact with gyttja at the level of $32.80 \mathrm{~m}$ a.s.l. This layer of gyttja is thin, only $7 \mathrm{~cm}$, and changes gradually to peat, which continues homogenously to the sediment sur- face (36.15 $\mathrm{m}$ a.s.l.) with a thin interlayer of clay-gyttja at the level of 34.85-34.90 $\mathrm{m}$ a.s.l. In the lowest part of the peat unit (approximately 32.87-33.00 m a.s.l.) marks of intensive gas fermentation and ebullition were observed.

An important observation in cores Etu1, Etu2, Etu3, Etu4, Taka1, Taka5 and Taka12 was related to the surface of the lowest unit of the core, clay. It was found to contain plant roots and traces of organic soil formation. The clay was also interpreted to be overconsolidated based on increased resistance to core penetration. This indicates that the clay unit had been above the water level before the accumulation of the upper soft sediment units of the cores began.

\section{I.2.AMS ${ }^{14} \mathrm{C}$-datings}

Two samples were taken from the core Taka10: a piece of a water chestnut seed at the level of 32.15 $\mathrm{m}$ a.s.l. (Taka10, upper sample), and a piece of pine bark at the level of $31.35 \mathrm{~m}$ a.s.l. (Taka10, lower sample). One pine bark sample was taken from the core Etu4, at the level of $33.72 \mathrm{~m}$ a.s.l. Results of the datings are in Table 1.

The lowest AMS dated sample (Taka10, Hela-868) is taken from the contact of gyttja and silty clay, showing the age of $8760 \pm 140 \mathrm{cal}$. B.P. The upper sample of the core Taka10 (Hela-867) is taken from the upper Trapa natans layer and has the age of $7590 \pm 50 \mathrm{cal}$. B.P. The sample from core Etu4 (Hela-866) is taken from the contact of gyttja and clay, showing the age of $2270 \pm 70$ cal. B.P.

\section{I.3. LOI and MS of the core TakalO}

The LOI and MS are presented in Fig. 3. From the bottom of the core LOI remains less than $10 \%$ until the sediment depth of $575 \mathrm{~cm}$ (31.55 m a.s.l.). Then it increases gradually and is ca. $35 \%$ at the sediment depth of $450 \mathrm{~cm}$ (32.80 m a.s.l.). Above this level LOI increases sharply to $85-90 \%$ at the sediment depth of ca. $430 \mathrm{~cm}$ (33.00 m a.s.l.). The next changes, which are also detectable in sediment lithostratigraphy, occur at the sediment depth of ca. $65 \mathrm{~cm}$ 


\section{Taka 10}

Susceptibility $\times 10-5 \mathrm{SI}$
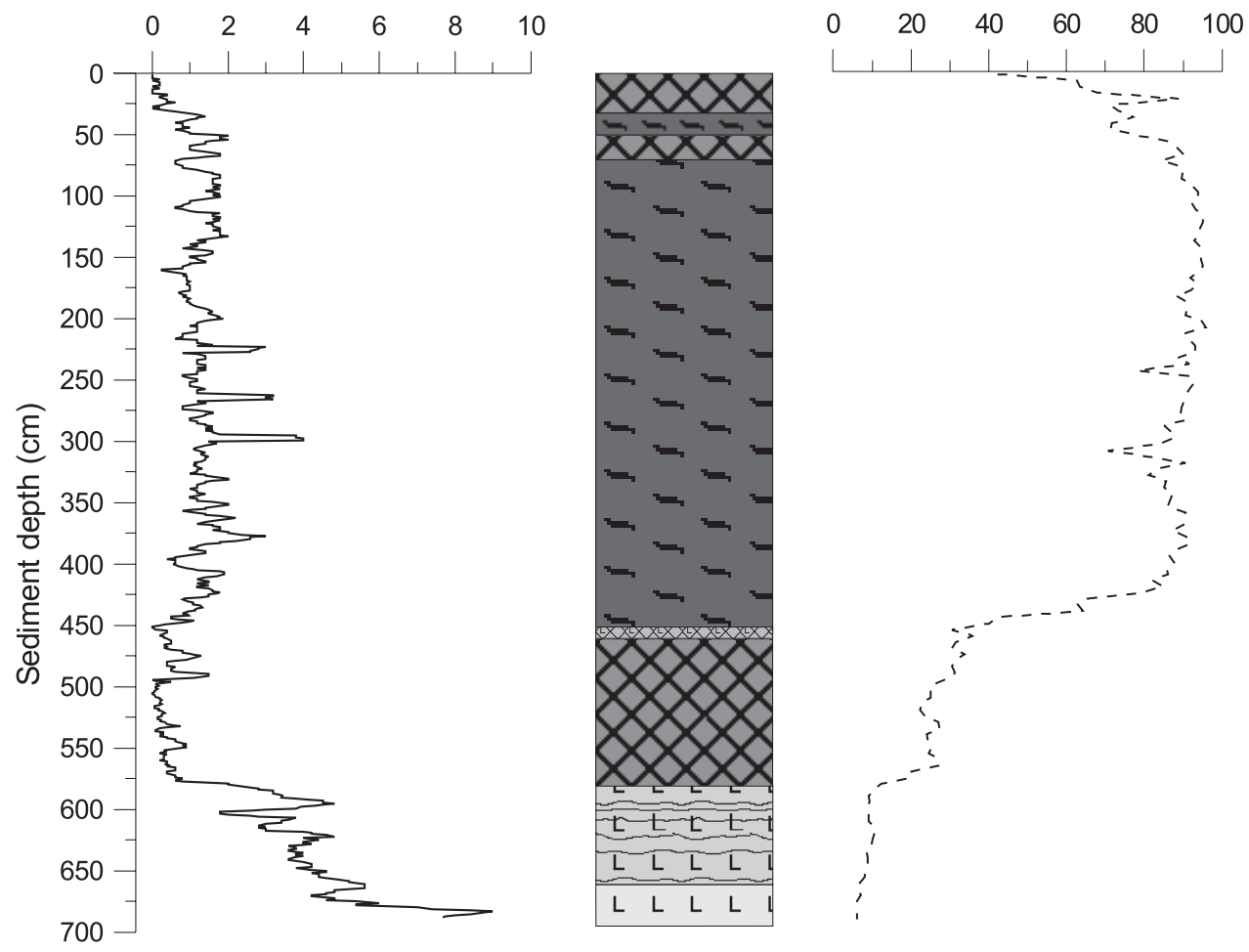

Fig. 3. Magnetic susceptibility, sediment lithostratigraphy and loss on ignition (LOI) of the core Taka I0 (Lake Takajärvi).

Table I. Results of the AMS I4C datings.

\begin{tabular}{lllllll}
\hline Lake \& Core & $\begin{array}{l}\text { Sample level } \\
(\mathbf{m} \text { a.s.l. })\end{array}$ & $\begin{array}{l}\text { Material } \\
\text { dated }\end{array}$ & $\begin{array}{l}\text { Lab. } \\
\text { number }\end{array}$ & $\begin{array}{l}\text { Age 14C } \\
\text { B.P. }\end{array}$ & $\begin{array}{l}\text { Age cal. } \\
\text { B.P. }\end{array}$ & Age cal. B.C. \\
\hline Etujärvi, Etu4 & 33.72 & Pine bark & Hela-866 & $2280 \pm 50$ & $2270 \pm 70$ & $320 \pm 70$ \\
Takajärvi, Taka10 & 32.15 & Trapa natans & Hela-867 & $6730 \pm 60$ & $7590 \pm 50$ & $5640 \pm 50$ \\
Takajärvi, Taka10 & 31.35 & Pine bark & Hela-868 & $7885 \pm 70$ & $8760 \pm 140$ & $6810 \pm 140$ \\
\hline
\end{tabular}


Table 2. Results of the surface sediment sample analyses

\begin{tabular}{lcccccccc}
\hline Sample & $\begin{array}{c}\text { W } \\
\%\end{array}$ & $\begin{array}{c}\text { LOI } \\
\%\end{array}$ & $\begin{array}{c}\mathrm{NH}^{4} \mathbf{C l}-\mathbf{P} \\
\mathrm{mg} \mathrm{g}^{-1} \mathrm{DW}\end{array}$ & $\begin{array}{c}\text { NaOH-P } \\
\mathrm{mg} \mathrm{g}^{-1} \mathrm{DW}\end{array}$ & $\begin{array}{c}\text { HCl-P } \\
\mathrm{mg} \mathrm{g}^{-1} \mathrm{DW}\end{array}$ & $\begin{array}{c}\text { Refractory-P } \\
\mathrm{mg} \mathrm{g}^{-1} \mathrm{DW}\end{array}$ & $\begin{array}{c}\text { Total-P } \\
\mathrm{mg} \mathrm{g}^{-1} \mathrm{DW}\end{array}$ & $\begin{array}{c}\text { Grain size median } \\
\mu \mathrm{m}\end{array}$ \\
\hline T1 & 94.8 & 31.1 & 0.038 & 0.278 & 0.329 & 0.279 & 0.924 & 128.8 \\
Taka1_surface & 94.6 & 91.0 & 0.074 & 0.326 & 0.044 & 0.781 & 1.226 & 41.7 \\
Taka2_surface & 95.0 & 45.9 & 0.036 & 0.156 & 0.156 & 1.873 & 2.222 & 113.3 \\
Taka3_surface & 92.4 & 31.9 & 0.017 & 0.096 & 0.201 & 1.467 & 1.782 & 127.5 \\
Taka4_surface & 94.6 & 32.1 & 0.020 & 0.133 & 0.143 & 1.672 & 1.969 & 104.7 \\
E1 & 89.7 & 25.4 & 0.046 & 0.174 & 0.209 & 1.223 & 1.653 & 86.1 \\
Etu1_surface & 87.7 & 22.4 & 0.023 & 0.099 & 0.217 & 0.946 & 1.284 & 7.4 \\
Etu2_surface & 93.4 & 22.1 & 0.028 & 0.416 & 0.180 & 0.848 & 1.472 & 7.7 \\
Etu3_surface & 90.7 & 21.2 & 0.006 & 0.334 & 0.157 & 1.089 & 1.586 & 6.5 \\
Etu4_surface & 86.9 & 21.8 & 0.014 & 0.289 & 0.145 & 1.091 & 1.538 & 9.0 \\
\hline
\end{tabular}

(36.60 $\mathrm{m}$ a.s.1.), where LOI decreases to ca. 70\%. At the sediment depth of $30 \mathrm{~cm}$ (37.00 m a.s.l.) LOI again increases to $90 \%$ and decreases then to ca. $40 \%$ at the sediment surface (37.30 $\mathrm{m}$ a.s.1.).

At the bottom of the core the MS is approximately $8 \times 10^{-5} \mathrm{SI}$. It decreases rapidly to ca. $4 \times 10^{-5} \mathrm{SI}$ at the sediment depth of $650 \mathrm{~cm}$ (30.80 m a.s.1.). At the sediment depth of $600 \mathrm{~cm}$ (31.30 m a.s.l.) MS has a peak to $5 \times 10^{-5} \mathrm{SI}$, and then it decreases again to $1 \mathrm{x}$ $10^{-5} \mathrm{SI}$ at sediment depth of $575 \mathrm{~cm}$ (31.55 m a.s.l.). Above this level, decrease continues until the sediment depth of $430 \mathrm{~cm}$ (33.00 $\mathrm{m}$ a.s.1.), where the value of MS is $1 \times 10^{-5} \mathrm{SI}$. Between levels $430 \mathrm{~cm}(33.00$ $\mathrm{m}$ a.s.1.) and $50 \mathrm{~cm}$ (36.80 $\mathrm{m}$ a.s.1.) MS is rather stable, and above this it increases to $0.5 \times 10^{-5} \mathrm{SI}$ at the sediment surface (37.30 $\mathrm{m}$ a.s.1.)

\subsection{Surface sediment samples and short cores}

\subsection{Surface sediment samples}

The results of surface sediment sample analyses are presented in Table 2. In Lake Takajärvi the highest value of LOI is at sample point Taka1_surface, where- as the lowest value was measured from the surface of the short-core, T1. The highest total phosphorus content was measured from sample Taka2_surface and the lowest from T1. Refractory phosphorus was the most important fraction in all Lake Takajärvi surface sediment samples, except for T1, where the $\mathrm{HCl}$ $P$ was the most significant fraction. The coarsest grain size was detected in sample T1, whereas the lowest was in sample Taka1_surface.

In Lake Etujärvi the properties of surface sediment are more consistent than in Lake Takajärvi. The difference between the highest (E1) and the lowest (Etu3_ surface) LOI values is only $4.2 \%$. The phosphorus content is also more even in Lake Etujärvi. The highest content was measured from sample E1 and the lowest from Etu1_surface. The refractory phosphorus was the most significant fraction in every surface sediment sample in Lake Etujärvi. The grain size is the only measured parameter that is not consistent in every sample. In sample E1 the mineral matter is remarkably coarser (grain size median $86.1 \mu \mathrm{m}$ ) than in other surface sediment samples. 


\subsection{Short cores}

\subsection{SCP dating}

The results of the SCP counting are shown in Fig. 4. The fossil fuel combustion and SCP concentration curves were fitted to coincide the rapid increase of fossil fuel burning during the 1960's and the observed increase of the SCP concentration in sediment. Also, the Neste Oil's oil refinery started in the mid-1960's, located ca. $25 \mathrm{~km}$ south-west from Askola municipality, has affected the studied lakes increasing the concentration of the SCP which, in the lower parts of the profiles, is extraordinary low.

In Lake Etujärvi the maximum of SCPs, approximately 2600 SCP g g $^{-1}$ DW was counted at the depth of 2-4 cm. Samples taken from the depth levels of 12-14, 16-18 and 18-20 cm were free of SCP.

In Lake Takajärvi only the lowest sample of the profile $(18-20 \mathrm{~cm})$ contained no SCP. The maximum amount of SCP, approximately $5100 \mathrm{SCP} \mathrm{g}^{-1} \mathrm{DW}$ was detected at the depth of $10-12 \mathrm{~cm}$. Above this level the amount of SCP fluctuates strongly.

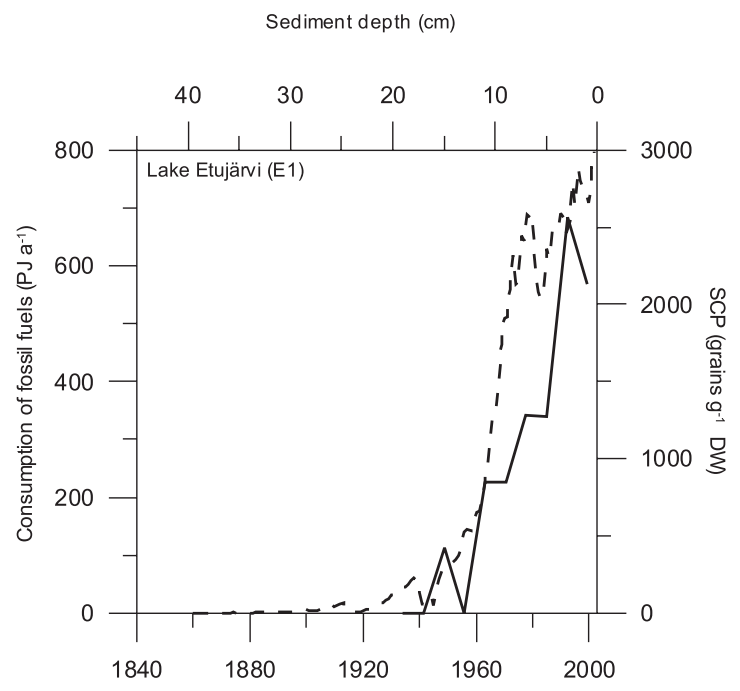

Year

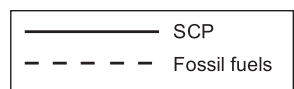

Fig. 4. Results of the spherical carbonaceous particles (SCP) analysis of the short cores EI (Lake Etujärvi) and TI (Lake Takajärvi) plotted against the annual consumption of fossil fuels in Finland (Statistics Finland, 2003).
In Lake Etujärvi W increases from the bottom of the core $(68 \%)$ to the surface $90 \%$ (Fig. 5). Between 14 to $10 \mathrm{~cm} \mathrm{~W}$ is stable, approximately $78 \%$, but between 10 to $8 \mathrm{~cm}$ increases rapidly to $86 \%$. LOI in Lake Etujärvi is much like with $\mathrm{W}$. The lowest value, $11 \%$ was detected from the lowest sample, and at the level of 10 to $8 \mathrm{~cm}$ there is rapid increase from 15 to $20 \%$. The highest value, $25 \%$, was measured from the surface sediment sample.

W and LOI of the short core in Lake Takajärvi are higher than in Lake Etujärvi. In the lowest sample $(18-20 \mathrm{~cm}) \mathrm{W}$ is $85 \%$ and LOI is $22 \%$, in the surface sample W increases gradually to $95 \%$ and LOI to $31 \%$.

\subsubsection{Grain size}

The grain size distributions of the short cores of lakes Etujärvi and Takajärvi are presented in Fig. 6. The core of Lake Etujärvi contains hardly any material coarser than $200 \mu \mathrm{m}$ below the depth of $15 \mathrm{~cm}$.

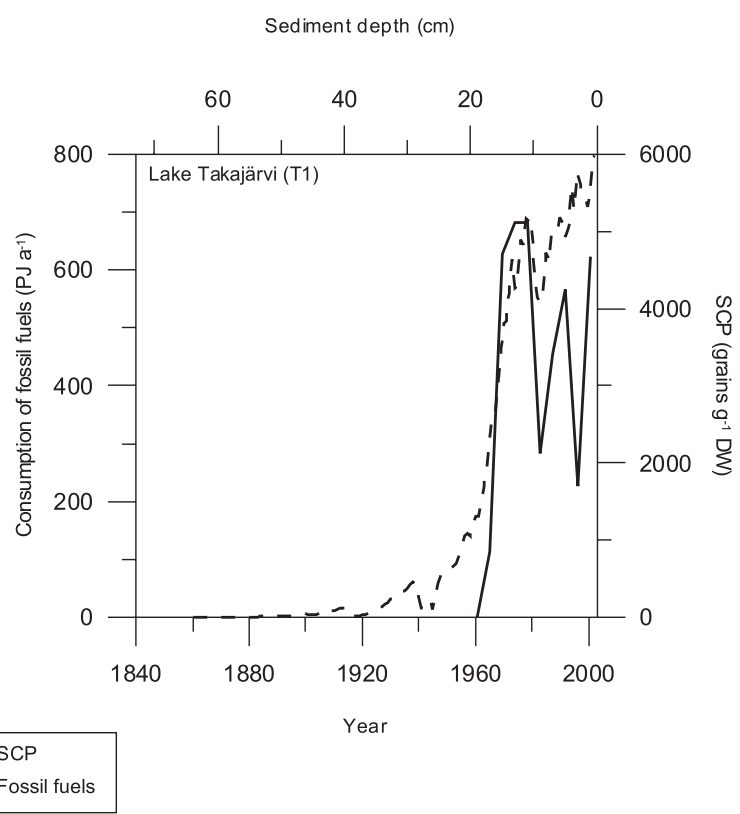

(Lake Takajirvi) plotted against the annual consumption of fossil fuels in Finland (Statistics Finland, 2003). 


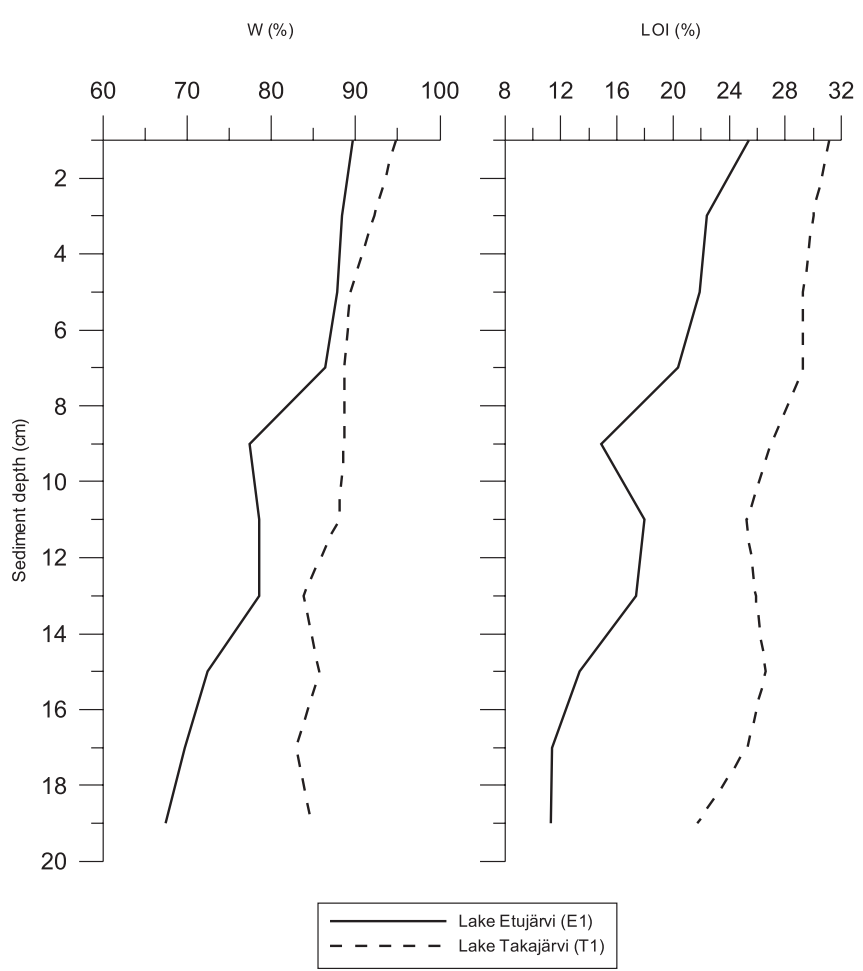

Fig. 5. The water content (W) and loss on ignition (LOI) of the short cores EI (Lake Etujärvi) and TI (LakeTakajärvi).

Above this level, the material coarser than $800 \mu \mathrm{m}$ is the dominant fraction of the mineral matter. In the three topmost samples there exist two distinct fractions, one approximately $200 \mu \mathrm{m}$ and the other, coarser, approximately $1800 \mu \mathrm{m}$ in median size.

In Lake Takajärvi the situation is almost the opposite. The lower part of the core contains mainly mineral matter coarser than $1000 \mu \mathrm{m}$. The proportion of the finer material increases continuously upwards in the core, and in the three topmost samples grains of approximately $300 \mu \mathrm{m}$ in size make the dominant fraction.

\subsubsection{Total phosphorus and phosphorus fractions}

The total phosphorus content and phosphorus fractions of the short core samples of lakes Etujärvi and Takajärvi are represented in Fig. 7. In general, the total phosphorus content is lower in Lake Etujärvi than in Lake Takajärvi, being $0.73 \mathrm{mg} \mathrm{g}^{-1} \mathrm{DW}$ in the low- est sample and $1.65 \mathrm{mg} \mathrm{g}^{-1} \mathrm{DW}$ in the surface sediment sample. The refractory $\mathrm{P}$ is the dominant fraction throughout the whole profile, and therefore the 8-10 cm sample has a lower value of total phosphorus, in the same way that it has a lower value of LOI.

The phosphorus content of the lowest subsample of Lake Takajärvi (1.42 $\left.\mathrm{mg} \mathrm{g}^{-1} \mathrm{DW}\right)$ is ca. twofold compared to the lowest subsample of Lake Etujärvi $\left(0.74 \mathrm{mg} \mathrm{g}^{-1} \mathrm{DW}\right)$. The maximal $\mathrm{P}$ content was detected from sample $2-4 \mathrm{~cm}, 2.01 \mathrm{mg} \mathrm{g}^{-1} \mathrm{DW}$. The surface sample and sample $6-8 \mathrm{~cm}$ differ from the general phosphorus content level of the core, being clearly lower. These differences are dependent on the refractory phosphorus, which is the major fraction in the short core of Lake Takajärvi.

\subsubsection{Diatom analysis and DITP}

The selected diatom taxa of Lake Etujärvi are presented in Fig. 8. The proportion of eutrophic plank- 

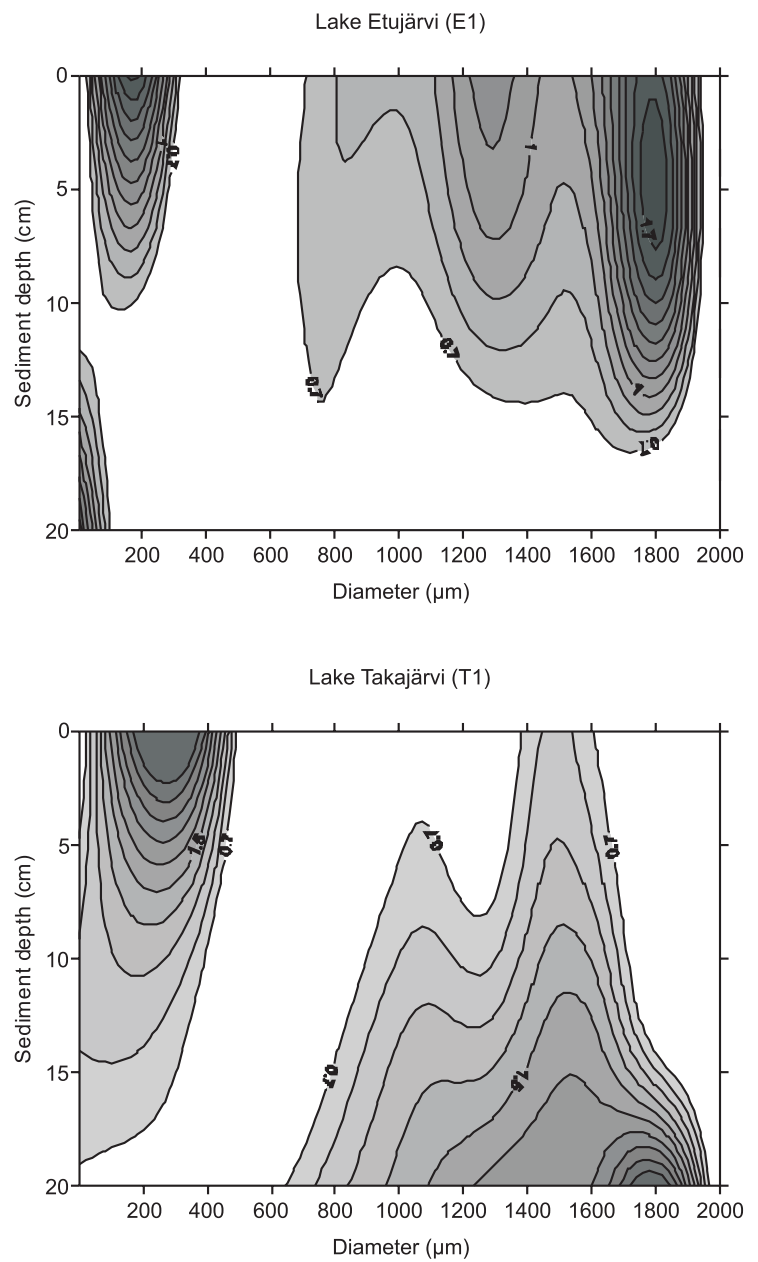

Fig. 6. Percentage values of grain size distribution of the short cores EI (Lake Etujärvi) and TI (Lake Takajärvi).

tonic taxa, such as Aulacoseira italica, A. granulata, A. ambigua, and Cyclotella meneghiniana increases in the upper half of the profile. In contrast, benthic species such as Pinnularia interrupta, Eunotia exigua and Frustulia rhomboides, which are common in the lower half of the profile, either decrease or decline in the topmost $10 \mathrm{~cm}$ of the core.

In Lake Takajärvi (Fig. 9) the changes in the diatom taxa are not as pronounced as those in Lake Etujärvi. Aulacoseira granulata, A. italica, A. ambigua, as well as Cyclotella pseudostelligera, Tabellaria flocculosa and Fragilaria pinnata var. pinnata are common in the whole profile.
The average value of DITP is approximately $25 \mu \mathrm{g}$ $1^{-1}$, slightly lower in Lake Etujärvi than in Lake Takajärvi (Fig. 10). In both lakes there exists a peak: in Lake Etujärvi ca. $35 \mu \mathrm{g} \mathrm{l}^{-1}$ at the sediment depth of $12-8 \mathrm{~cm}$, and in Lake Takajärvi ca. $45 \mu \mathrm{g} \mathrm{l}^{-1}$ at the sediment depth of 16-13 cm.

\section{Discussion}

\section{I. Lake level fluctuations during the Holocene}

Lithostratigraphical evidence connected with the three AMS radiocarbon dates indicates early Holocene water-level fluctuations in studied basin (Fig. 11). The lakes dried up totally soon after isolation, ca. 9500 cal. B.P. This is evidenced by overconsolidation of basal soil and remains of roots and other organic material in the lowermost parts of the cored sections. The decline in water level during the early Holocene is comparable to that recorded, e.g., from Lapland (Hyvärinen \& Alhonen, 1994) and from Lake Juusa, Estonia (Punning et al., 2005). Overall drier conditions around the Baltic Sea at that time have also been demonstrated in a comprehensive review of Harrison et al. (1996).

Dry conditions changed towards wetter ones at the latest $8700 \mathrm{cal}$. B.P., which is recorded as the onset of lacustrine sedimentation. The water level rose during the next 1000-2000 years, but remained lower than at present. The sediment lithostratigraphy (see Fig. 2) from different parts of the lake represents alternating peat and gyttja depositions, indicating a fluctuating water level of about 35-36 meters a.s.l. (Fig. 11).

According to the sediment stratigraphy and the AMS dated sample from Etu4 the continuous rise of water level began more than 2000 cal. B.P. and continued until the $19^{\text {th }}$ century. Since ca. 2000 cal. B.P. continuous gyttja deposition has prevailed in the deepest parts of the basin. The trend coincides with that described e.g. from Lake Bysjön (Digerfeldt, 1988), Lake Juusa (Punning et al., 2005) and is also in agreement with the data set presented by Harrison et al. (1996). 


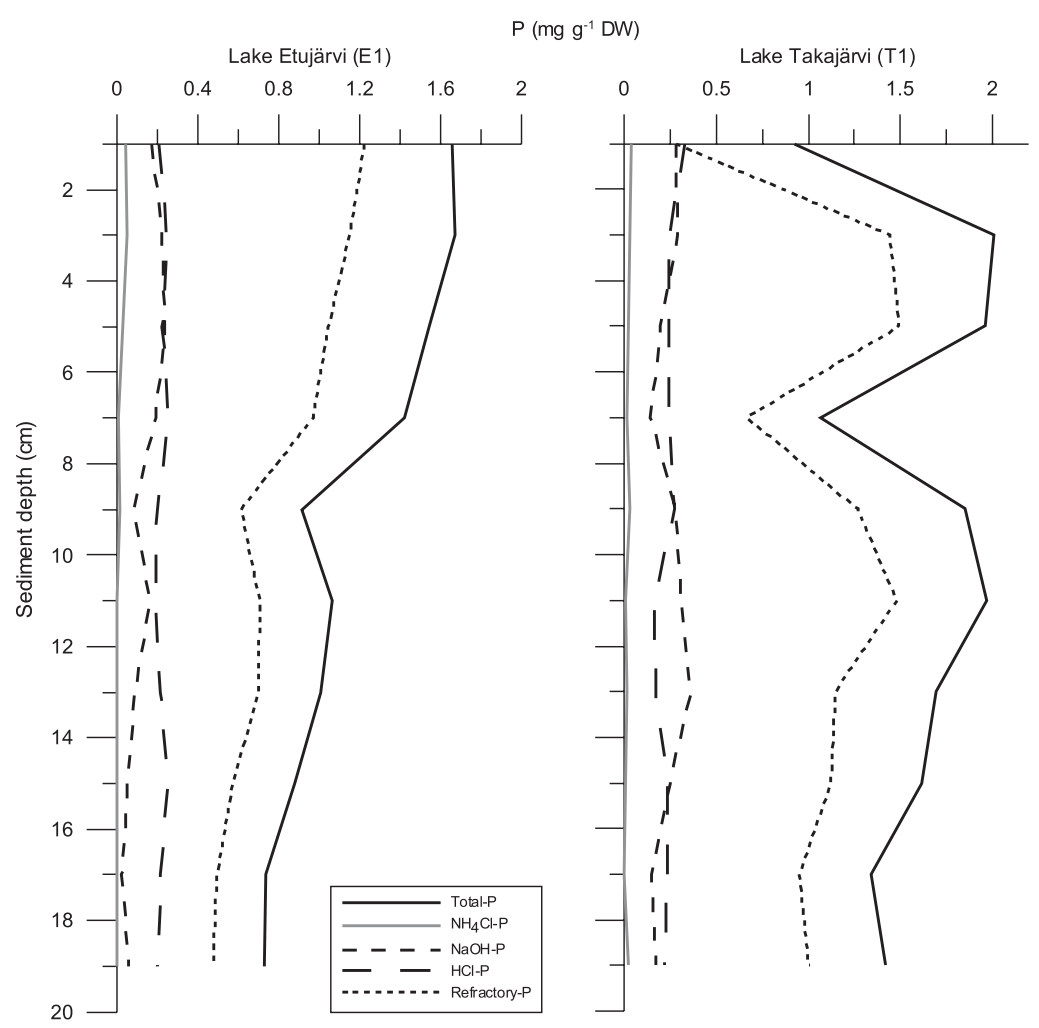

Fig 7. The sedimentary total phosphorus and phosphorus fractions of the short cores EI (Lake Etujärvi) and TI (Lake Takajärvi).

This also fits with the common understanding of Holocene climate having a dry and warm early phase and a fluctuating middle phase followed by a cooler and wetter late phase, beginning ca. $2500 \mathrm{cal}$. B.P. (e.g. Hyvärinen \& Alhonen, 1994; Donner, 1995; Heikkilä \& Seppä, 2003). There is room for smallscale fluctuations in mid-Holocene, similar to those discussed in the cladoceran-based study of Sarmaja-Korjonen (2001). However, the resolution and number of our datings is not high enough to allow fine resolution fluctuations to be sorted out.

\subsection{Occurrence of water chestnut in Lake Takajärvi}

During the coring of Lake Takajärvi, Trapa natans was detected at the coring point Taka10. It occurred as two distinct horizons (Fig. 2), the upper one being approximately $10 \mathrm{~cm}$, and the lower one $5 \mathrm{~cm}$ thick. The AMS dated T. natans (see Table 1 ) is taken from the upper horizon.

There are several descriptions of occurrences of $T$. natans in Finland, since the 1920's (Sauramo, 1929; Lumiala, 1943; Valovirta, 1949) and most recently from the 1990's and 2000's (Korhola \& Tikkanen, 1997; Lempiäinen, 2002). Vuorela and Aalto (1982) have described a T. natans-finding from a Neolithic dwelling site at Pennala, Orimattila, approximately $40 \mathrm{~km}$ north from Lake Takajärvi. However, this study is the first providing an AMS-dated T. natans occurrence from Finland.

T. natans has been considered as evidence of warmer summer conditions, and the disappearance of it is usually connected with the cooling of the climate and oligotrophication with a subsequent infilling of the water chestnut lakes (e.g., Alhonen, 1964; Donner, 


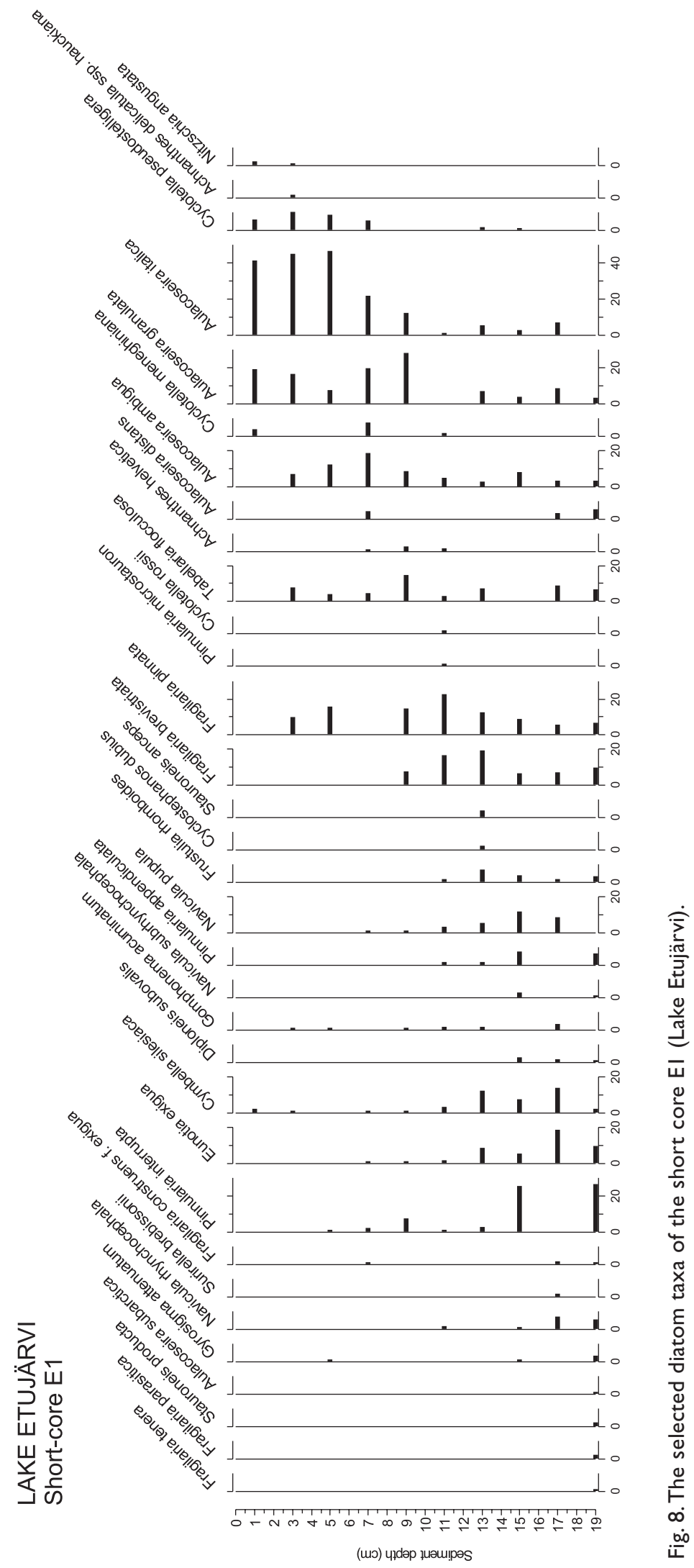




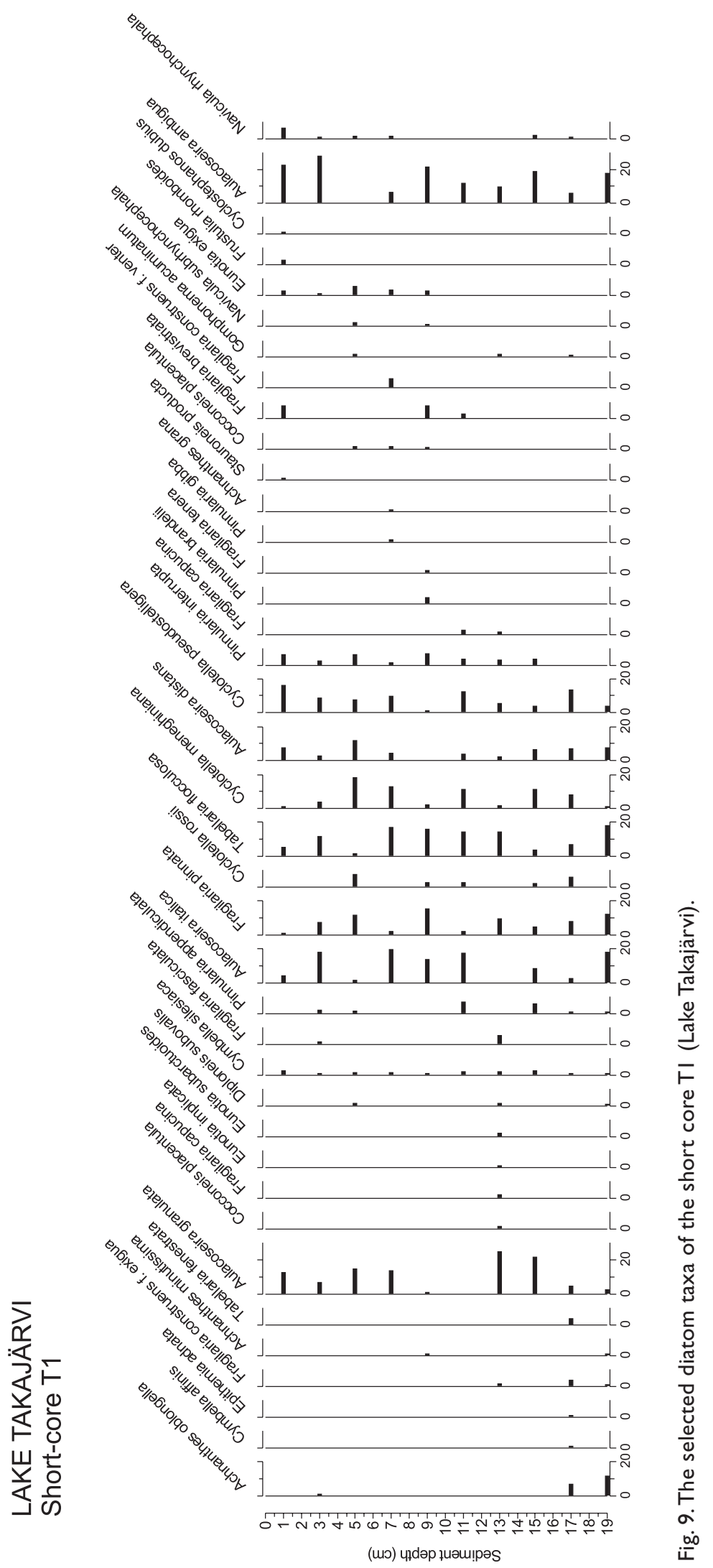




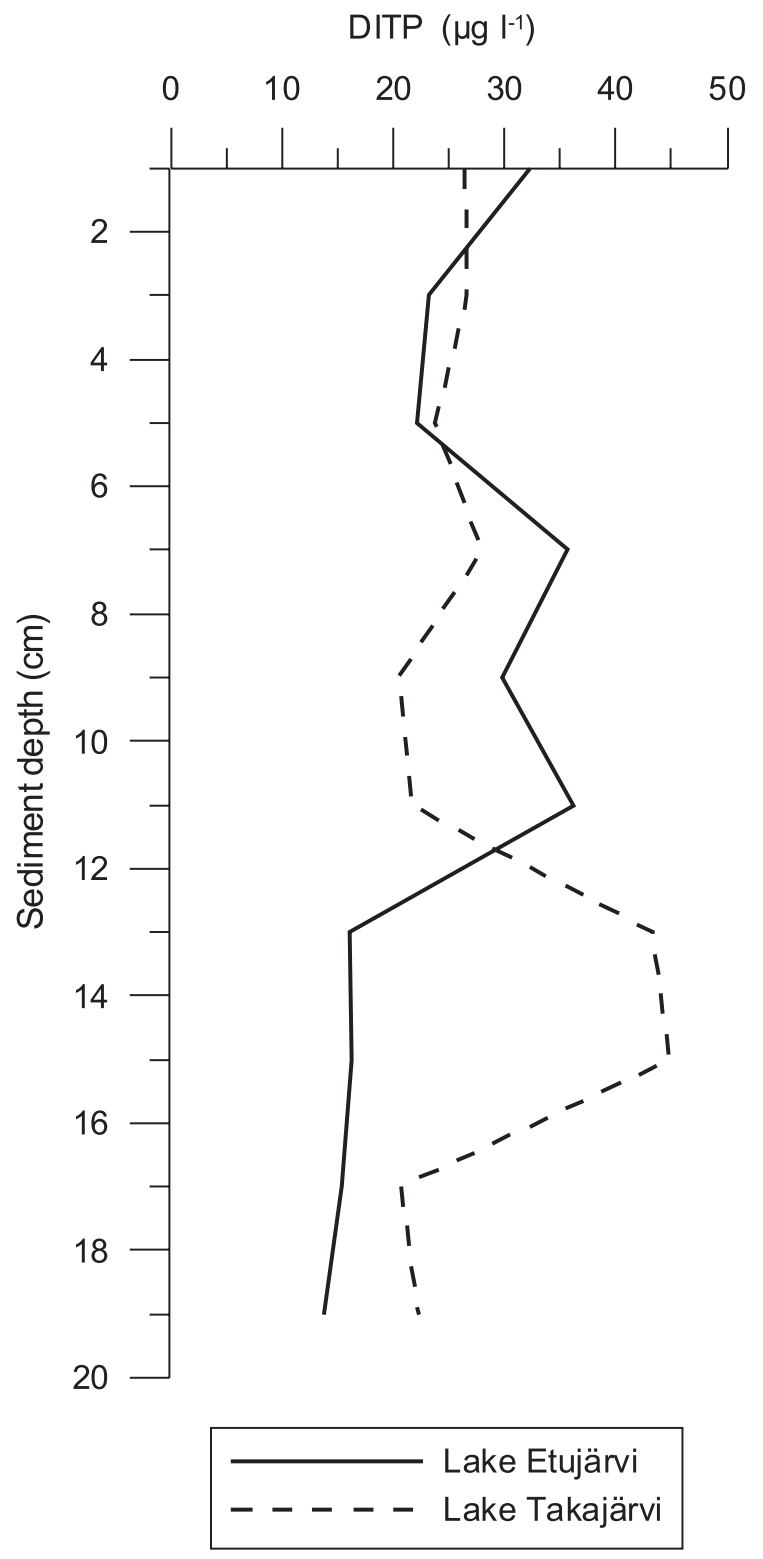

Fig. 10. The diatom inferred total phosphorus (DITP) of the short cores EI (Lake Etujärvi) and TI (LakeTakajärvi).

1995). Moreover, Korhola \& Tikkanen (1997) argued that the decline of $T$. natans was mainly due to infilling of shallow, eutrophied lakes and also acidification of the remained forest lakes.

The age of the $T$. natans-sample from the upper Trapa horizon proves, that occurrence of $T$. natans in Lake Takajärvi was most intensive during the ear- ly phases of the Holocene climate optimum in Finland (e.g. Heikkilä \& Seppä, 2003). The infilling and increased peat deposition of Lake Takajärvi caused the disappearence of $T$. natans at a rather early stage during this warm interval. Most likely Lake Takajärvi was rather humic and (see Fig. 3) before its infilling, and it is unlikely that actual oligotrophication would have happened. Results of this study seem to support the conception that the decline of water chestnut took place already during the Holocene thermal maximum and was largely connected to basin infilling and pronounced water level fluctuations in littoral $T$. natans habitats.

\subsection{Implications for lake management}

The results of the study show that the artificial eutrophication has caused changes not only to the water quality, but also to the sediments of lakes Etujärvi and Takajärvi during the last few decades. However, concerning the recreation activities of the lake, eutrophication is not the most significant factor causing the deterioration of the water quality in these lakes.

Water level changes have affected the character of the studied lakes several times during the Holocene. A gradual and continuous rise of water level facilitated the growth of thick peat accumulations on the shores of especially Lake Takajärvi (see Fig. 1). These peat accumulations, which are facing continuous erosion on the shoreline, are causing a remarkable load of humic substances on the lakes. The presence of these humic substances is one factor making the massive occurrences of Gonyostomum semen possible (e.g. Salonen \& Rosenberg, 2000) and accelerating the consumption of oxygen during wintertime. This increases the risk of internal phosphorus load and diminishes the Secchi depth of the lakes.

As presented in figures 5 and 7, the LOI of the sediment and the phosphorus content of the sediment have an increasing trend especially in Lake Etujärvi. In Lake Takajärvi the heavier load from the peat accumulations has partially shaded the impact of the phosphorus load from the catchment area. This major role of organic matter in sedimentation can be seen also in 


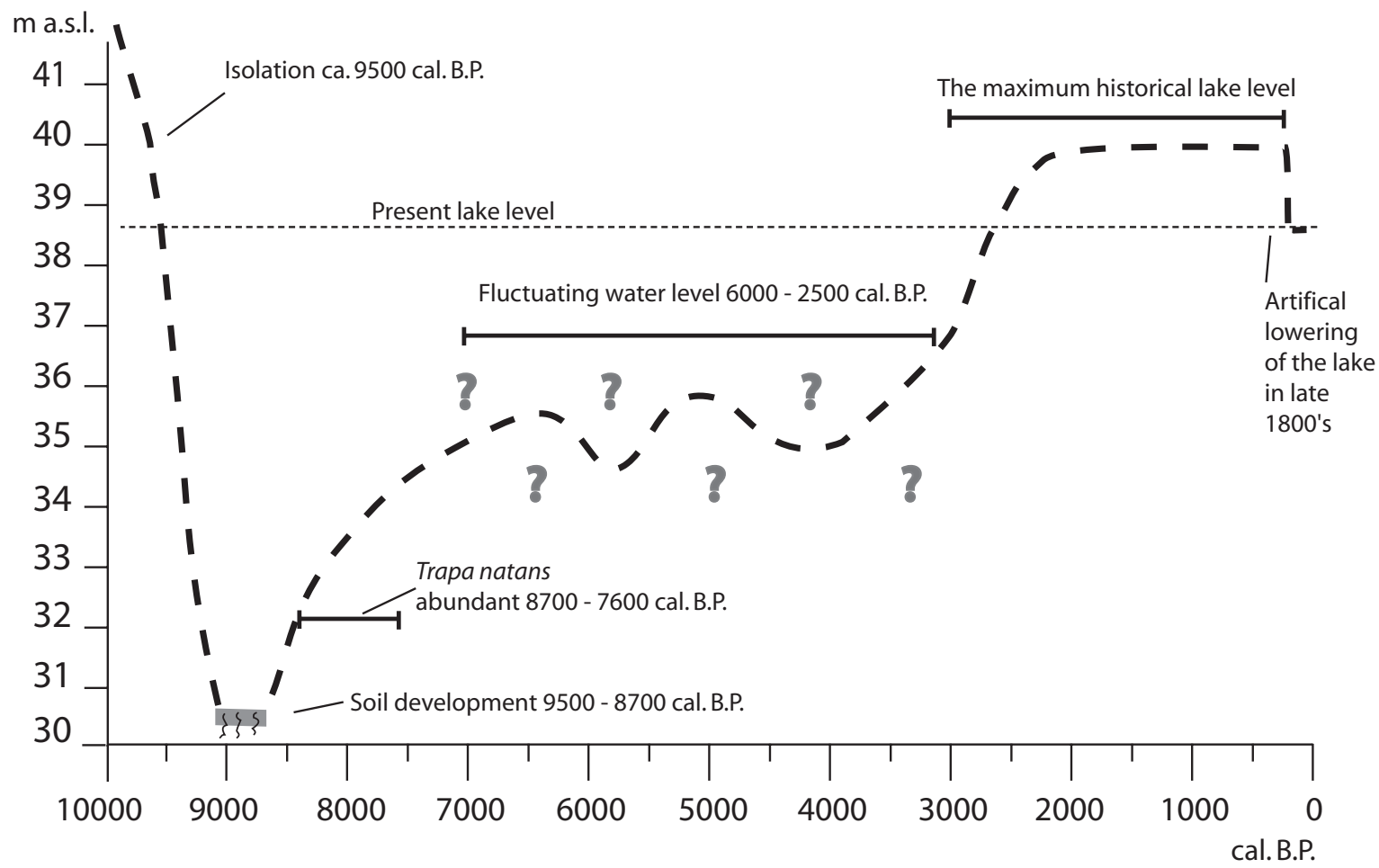

Fig I I. Possible lake level fluctuations in the studied basins during the Holocene. The dashed line is fitted to all datings and lithological observations.

surface sediment samples from both lakes (Table 2). The sedimentary phosphorus content, which actually is not especially high in these lakes, consists mostly of refractory phosphorus. Only in the surface sample taken from the point $\mathrm{T} 1$ is the amount of the $\mathrm{HCl}$ extracted phosphorus greater than the amount of the refractory phosphorus. This is probably connected to the construction and maintenance of a sandy swimming beach approximately 70 meters northwest from the sampling point. Another factor equalizing the detected smoother increase of phosphorus content in Lake Takajärvi is the time span the core represents. The results of the SCP counting indicate that the age of the bottom sample of the Lake Takajärvi core is approximately 35-40 years, representing the mid1960 's, whereas the bottom sample of Lake Etujärvi is approximately 20 years older.

The results of the grain size analysis support the idea of a coinciding sedimentation history for the lakes during the last few decades. Changes caused by the intensified land use during the late 1950's and 1960 's have affected to grain size distribution of the accumulated mineral matter. The change seems to be detectable also in LOI, but its intensity is low, most likely because of the humic load from the peat areas. The dating based on the SCP counting shows that these changes have occurred simultaneously in both lakes. In Lake Etujärvi the beginning of the coarser material sedimentation can be detected at the sediment depth of ca. $16 \mathrm{~cm}$ (late 1950's). The profile of Lake Takajärvi covers only a period from the mid1960's to the present day. Therefore the onset of the coarse material accumulation cannot be seen, but the increase of the finer material proportion $(<400 \mu \mathrm{m})$ again in the early 1970's is evident in both lakes.

The diatom taxa of the studied lakes reflect the eutrophication. Changes in the taxa are more distinct in the profile of Lake Etujärvi. Again, this supports the 

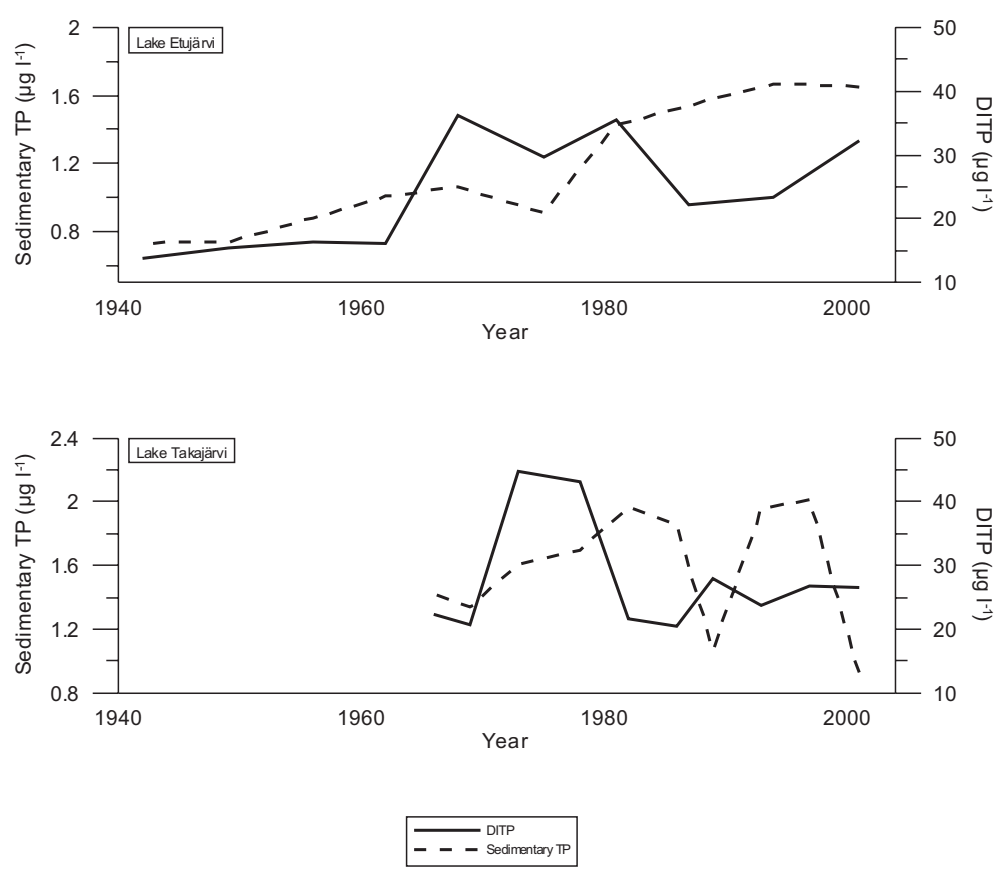

Fig 12. The temporal trends of the diatom inferred total phosphorus (DITP) and the sedimentary total phosphorus (TP) in the studied lakes. Dating is based on the spherical carbonaceous particles analysis (SCP).

different deposition rates for the cores. In the Lake Takajärvi core the background situation before the most intensive agriculture can not be seen and therefore its diatom taxa seem to be more constant. The most common species in the profile of Lake Takajärvi are the same Aulacoseira- and Cyclotella- species, which are common also in the upper half of the Lake Etujärvi profile. The major change towards the more eutrophicated circumstances in Lake Etujärvi begins at the sediment depth of $12 \mathrm{~cm}$ (ca. mid-1960's), which also equates with the age of the bottom sample of the profile of Lake Takajärvi.

DITP supports the interpretation of the rather simultaneous eutrophication of the studied lakes. The most severe increase in the DITP is connected to the late 1970's both in Lake Etujärvi and Lake Takajärvi (see Fig. 12). The sedimentary phosphorus seems to react to the increased load showed by DITP with a clearly detectable delay, but more accurate consideration of this delay is not possible because of the rather coarse sample frequency of this study. However, the DITP slightly underestimates the phosphorus con- centration compared to the results of the water quality measurements, most likely due to the large littoral area habitats of the lakes. The same kinds of results were also found by Kauppila et al. (2002b) and Kauppila \& Valpola (2003). The steep decrease in the concentration of the sedimentary total phosphorus in the surface of the Lake Takajärvi short core profile is due to the decrease of the refractory phosphorus and probably connected with the construction and maintenance of the recreational beach nearby the sampling site. The possibility of an internal load exists in both of the lakes, especially in Lake Takajärvi, which has suffered anoxic conditions during the winters. Because of the small volume of the lakes, the impact of such an additional load could be severe. The amount of $\mathrm{NaOH}$-extracted phosphorus is, however, rather small, and has been very stable except for the sharp minimum during the 1990's in Lake Takajärvi.

For the further management of the twin lakes the minimization of the nutrient load from the catchment is of high importance (e.g., Mattila, 2005). Active restoration methods, such as oxidation, gypsum 
treatment of the basins (Varjo et al., 2003) or biomanipulation may provide temporary remediation in the case of the Askola lakes, but will not solve the basic problem. Preventing the erosion of the peat accumulations would decrease the amount of humic sludge on the beaches and slow down the upfilling of Lake Takajärvi. Due to the annual ice cover this is, however, difficult and the results would be unstable. Another possibility would be the dredging of the peat deposits, but the massive amount of the dredged material and its treatment would cause serious problems for lake environment and untenable expenses.

\section{Conclusions}

Results indicate that sediment records in small headwater lakes having only a minor proportion of groundwater flow can offer sensible proxies for determining centennial to millennial scale water level fluctuations. The studied lakes Etujärvi and Takajärvi have experienced pronounced variations in lake level during the last 10000 years. There is strong evidence indicating that the basin dried up completely during the early Holocene, ca. 9500-8700 cal. B.P. This dry period was followed by a varying, few metres rose in water level, which resulted in more variable lake environment during the Mid-Holocene. However, the lake level probably rose to its highest stand only 2500 cal. B.P. as wet and cool climate conditions began.

The observations considering Trapa natans can be connected to the observed trends in water level fluctuation. It is probable that at least in the small, shallow lakes on the coastal area of Finland, such as studied basin, the reason for the disappearance of the water chestnut is a combination of climate, water level fluctuations, and infilling of the pools. According to the datings presented in this study, the disappearence of T. natans occurred in studied basin already in the early stages of the Holocene thermal maximum.

The intensive peat accumulation in Lake Takajärvi and in the southern area of Lake Etujärvi is a distinctive feature of the twin lakes' history. It has restricted the open water area of the lakes and caused a heavy humic load with its consequences. The interaction of the peat accumulation and the cultural eutrophication of both lakes since the 1960's has generated the present situation in which the water quality and therefore the lakes' recreational value have impaired. The restoration or management of these lakes is not a straightforward task. The dredging of the peat accumulations would cause a long-lasting state of unstable sedimentation and accelerated oxygen consumption, which would probably lead to problems such as accelerated internal load and destruction of fish populations.

This study gives an example of the situation in which thorough paleolimnological knowledge of the history of the lake provides the opportunity to consider the goal and tools of the remediation process reasonably.

\section{Acknowledgements}

The authors would like to thank Dr. Tommi Kauppila for the reconstruction of the DITP and M.Sc. Jutta Forsell for the laboratory work. Dr. Anu Kaakinen and Dr. Antti Ojala are thanked for their valuable fieldwork assistance, and the municipality of Askola for funding of the analyses. Comments by Matti Tikkanen, Atko Heinsalu and an anonymous referee greatly improved the manuscript.

\section{References}

Agrawal, Y.C., McCave, I.N. \& Riley, J.B., 1991. Laser diffraction size analysis. In: Syvitski, J.P.M. (ed.) Principles, Methods and Application of Particle Size Analysis. Cambridge University Press, Cambridge, p. 119-128.

Alalammi, P., (ed.) 1987. Atlas of Finland, 131: Climate. National Board of Survey and Geographical Society of Finland, Helsinki, $31 \mathrm{p}$.

Alhonen, P., 1964. Radiocarbon age of waternut (Trapa natans L.) in the sediments of Lake Karhejärvi, S.W. Finland. Memoranda Societas Fauna \& Flora Fennica, Vol. 40, 192-197.

Alhonen, P., 1966. Vesipähkinän (Trapa natans L.) aika jääkauden jälkeisessä Suomessa. Summary: Holocene occurrence of waternut (Trapa natans L.) in Finland. LounaisHämeen Luonto 83, 71-78.

Almquist-Jacobsson, H., 1995. Lake-level fluctuations at Ljustjärnen, central Sweden and their implications for the Holocene climate of Scandinavia. Palaeogeography, Palaeoclimatology, Palaeoecology 118, 269-290.

Anttila, V., 1967. Järvenlaskuyhtiöt Suomessa. Kansatieteel- 
linen Arkisto 19. German summary: Die Seesenkungsgenossenschaften in Finnland. Suomen muinaismuistoyhdistys, $360 \mathrm{p}$.

Arnaud, F., 2005. Discriminating bio-induced and detrital sedimentary processes from particle size distribution of carbonates and non-carbonates in hard water lake sediments. Journal of Paleolimnology 34, 519-526.

Bengtsson, L. \& Enell, M., 1986. Chemical analysis. In: Berglund, B. (ed.). Handbook of Holocene Palaeoecology and palaeohydrology. John Wiley \& Sons, Chichester, p. 405-451.

Boyle, J., 2004. A comparison of two methods for estimating the organic matter content of sediments. Journal of Paleolimnology 31, 125-127.

Dalrymple, R.W. \& Carey, J.S., 1990. Water-level fluctuations in Lake Ontario over the last 4000 years as recorded in the Cataraqui River Lagoon, Kingston, Ontario. Canadian Journal of Earth Sciences 27, 1330-1338.

Digerfeldt, G., 1988. Reconstruction and regional correlation of Holocene lake-level fluctuations in Lake Bysjön, South Sweden. Boreas 17, 165-182.

Donner, J., 1995. The Quaternary history of Scandinavia. Cambridge University Press, Cambridge, 200 p.

Erkamo, V. \& Backman, A.L., 1960. Trapa natansin subfossiililöytöjä. In: Aario, L. (ed.) Suomen Kartasto (Atlas of Finland), Helsinki, Folio 10.

Eriksson, B., 1966. Vesipähkinän (Trapa natans L.) postglasiaalisesta esiintymisestä Suomessa. M.Sc. Thesis, Department of Botany, University of Helsinki, Finland.

Eronen, M., 1974. The history of the Litorina Sea and associated Holocene events. Commentationes Physico-Mathematicae 44 (4), 79-195.

Håkanson, L. \& Jansson, M., 1983. Principles of lake sedimentology. SpringerVerlag. Berlin, 316 p.

Harrison, S.P., YU, G. \& Tarasov, P.E., 1996. Late Quaternary Lake-Level Record from Northern Eurasia. Quaternary Research 45, 138-159.

Heikkilä, M. \& Seppä, H., 2003. A 11,000 yr palaeotemperature reconstruction from the southern boreal zone in Finland. Quaternary Science Reviews 22, 541-554.

HERTTA, 2005. Surface water data basis of Finnish Environment Centre.

Hieltjes, A. \& Lijklema, L., 1980. Fractionation of inorganic phosphates in calcareous sediments. Journal of Environmental Quality 9, 405-407.

Hyvärinen, H. \& Alhonen, P., 1994. Holocene lake level changes in the Fennoscandian tree-line region, western Finnish Lapland: diatom and cladoceran evidence. The Holocene 4, 251-258.

Hyvärinen, H., 1999. Shore Displacement and Stone Age Dwelling Sites near Helsinki, Southern Coast of. Finland. In: Huurre, M. (ed.) Dig it all: papers dedicated to Ari Siiriäinen. Helsinki, Finnish Antiquarian Society, Archaeological Society of Finland, p. 79-89.

Kansanen, P.H., Jaakkola, T., Kulmala S. \& Suutarinen, R., 1991. Sedimentation and distribution of gammaemitting radionuclides in bottom sediments of southern Lake Päijänne, Finland, after the Chernobyl accident. Hydrobiologia 222, 121-140.

Kauppila, T., Moisio T. \& Salonen V.-P., 2002a. A diatom based inference model for autumnal epilimnetic total phosphorus concentration and its application to a presently eutrophic boreal lake. Journal of Paleolimnology 27, 261-273.

Kauppila, T., Moisio T. \& Salonen, V.-P., 2002b. Diatom inferred increase in limnetic phosphorus concentration and the associated changes in sedimentary phosphorus fractions in Valkjärvi, a lake in Kärkölä, Finland. Boreal Environmental Research 7, 27-40.

Kauppila, T. \& Valpola, S., 2003. Response of a shallow boreal lake to recent nutrient enrichment - implications for diatom-based phosphorus reconstructions. Hydrobiologia 495, 47-58.

Korhola, A.A. \& Tikkanen, M.J., 1997. Evidence for a more recent occurrence of water chestnut (Trapa natans L.) in Finland and its palaeoenvironmental implications. The Holocene 7, 39-44.

Krammer, K. and Lange-Bertalot, H., 1986. Bacillariophyceae 2/1. Naviculaceae. In: Ettl, H.J., et al. (eds.) Süßwasserflora von Mitteleuropa. Gustav Fisher Verlag, Stuttgart, p. 876.

Krammer, K. and Lange-Bertalot, H., 1988. Bacillariophyceae 2/2. Bacillariaceae, Epithemiaceae, Surirellaceae. In: Ettl, H.J. et al. (eds.) Süßwasserflora von Mitteleuropa. Gustav Fisher Verlag, Stuttgart, p. 596.

Krammer, K. and Lange-Bertalot, H., 1991a. Bacillariophyceae 2/3. Centrales, Fragilariaceae, Eunotiaceae. In: Ettl, H.J. et al. (eds.) Süßwasserflora von Mitteleuropa. Gustav Fisher Verlag, Stuttgart, p. 576.

Krammer, K. and Lange-Bertalot, H., 1991b. Bacillariophyceae 2/4. Achnanthaceae, Kritische ergänzungen zu Navicula (Lineolatae) und Gomphonema. In: Ettl, H.J. et al. (eds.) Süßwasserflora von Mitteleuropa. Gustav Fisher Verlag, Stuttgart, p. 437.

Laitakari, I. \& Simonen, A., 1962. Lapinjärvi. Geological map of Finland 1:100 000, pre-Quaternary rocks, sheet 3022, Geological Survey of Finland.

Laitakari, I. \& Simonen, A., 1963. Lapinjärvi. Explanation to the geological map of Finland 1:100 000, pre-Quaternary rocks, sheet 3022, 48 p (in Finnish with English summary).

Lappalainen, E. \& Hänninen, P., 1993. Suomen turvevarat. Summary: The peat reserves of Finland. Geologian tutkimuskeskus. Tutkimusraportti 117, $118 \mathrm{p}$.

Lempinen, P., Penttilä, S., Savola, P. \& Taponen, T., 2002. Uudenmaan järvien tehokalastusprojekti. In: Penttilä, S. (ed.) Uudenmaan järvien tehokalastusprojekti. Kala- ja riistahallinnon julkaisuja 61/2002, 84 p.

Lempiäinen, T., 2002. Vesipähkinä (Trapa natans) neoliittikautisen ihmisen hyötykasvina Riihimäen Sinivuokkoniemessä. In: Matiskainen, H. (ed.) Riihimäen esihistoria. Riihimäen kaupunginmuseo, Riihimäki, p. 145- 
$147 ; 156-159$.

Lumiala, O.V., 1943. Zwei Moorprofile aus Siilinjärvi, dem nördlichsten bekannten Fundort fossiler Trapa natans in Finnland. Comptes Rendus de la Société Géologique de Finlande 15, 2-20.

Mattila, H., 2005. Ulkoisen kuormituksen vähentäminen. In: Ulvi, T. \& Lakso, E. (eds.) Järvien kunnostus. Ympäristöopas 114, Suomen ympäristökeskus, Edita Publishing, Helsinki, p. 139-149.

Murphy, J. \& Riley, J.P., 1962. A modified single solution method for the determination of phosphate in natural waters. Analytica Chimica Acta 27, 31-36.

Olin, M., 2005. Fish communities in South-Finnish lakes and their responses to biomanipulation assessed by experimental gillnetting. Ph.D. thesis, University of Helsinki, Finland. 32 p.

Olin, M., Rask, M., Ruuhijärvi, J., Keskitalo, J., Horppila, J., Tallberg, P., Taponen T., Lehtovaara A. \& Sammalkorpi, I., 2006. Effects of biomanipulation on fish and plankton communities in ten eutrophic lakes of southern Finland. Hydrobiologia, in press.

Possnert, G., 1984. AMS with the Uppsala EN tandem accelerator. Nuclear Instruments and Methods in Physics Research Section B: Beam Interactions with Materials and Atoms 5, 159-162.

Possnert, G., 1990. Radiocarbon dating by the Accelerator Technique. Norwegian Archaeological Review 23(12), 30-37.

Punning, J-M., Koff, T., Kadastik, E. \& Mikomägi, A., 2005. Holocene lake level fluctuations recorded in the sediment composition of Lake Juusa, southeastern Estonia. Journal of Paleolimnology 34, 377-390.

Reunanen, S., 2003. Askolan Etu- ja Takajärven kunnostuksen haasteet. Uudenmaan ympäristökeskus, Moniste $117,40 \mathrm{p}$.

Rose, N.L., 1990. A method for the extraction of carbonaceous particles from lake sediment. Journal of Paleolimnology 3, 45-53.

Salonen, K. \& Rosenberg, M., 2000. Advantages from diel vertical migration can explain the dominance of Gonyostomum semen (Raphidophyceae) in a small, steeply-stratified humic lake. Journal of Plankton Research 22(10), 1841-1853.

Sarmaja-Korjonen, K., 2001. Correlation of fluctuations in cladoceran planktonic: littoral ratio between three cores from a small lake in southern Finland: Holocene waterlevel changes. The Holocene 11, 53-63.

Sauramo, M., 1929. The Quaternary Geology of Finland. Bulletin de la Commission géologique de Finlande 86, $1-110$.

Sauramo, M., 1958. Die Geschichte der Ostsee. Annales Academiae Scientiarum Fennicae, Ser. A III, (51), 1522.

Slota, P.J., Jull, A.J., Linick, T.W. \& Toolin, L.J., 1987. Preparation of small samples for ${ }^{14} \mathrm{C}$ accelerator targets by catalytic reduction of CO. Radiocarbon 29, 303-306.
Statistics Finland, 2003. The annual combustion of fossil fuels in Finland.

Troels-Smith, J., 1955. Karakterisering af löse jordarter. Danmarks Geologiske Undersögelse, IV Raekke 3:10. $73 \mathrm{p}$.

Tynni, R. \& Kukkonen, E., 1968. Lapinjärvi. Geological map of Finland 1:100 000, Quaternary deposits, sheet 3022, Geological Survey of Finland.

Tynni, R., Hyyppä, J. \& Valovirta, V., 1976. Explanation to the geological map of Finland 1:100 000, Quaternary deposits, sheet 3022, 40 p. (In Finnish with English summary).

Valovirta, V.E., 1949. Vesipähkinä (Trapa natans) Evijärvellä. Geologi 1, 39.

Valovirta, V.E., 1957. Vesipähkinästä (Trapa natans L.). Geologi 9, 4-5.

Valovirta, V.E., 1960. Paläobotanische Untersuchung über einen nördlichen Fundort subfossiler Trapa natans L. in Süd-Pohjanmaa. Comptes Rendus de la Société Géologique de Finlande 32, 41-65.

Varjo, E., Liikanen, A., Salonen V.-P. \& Martikainen P.J., 2003. A new gypsum based technique to reduce methane and phophorus release from sediments of eutrophied lakes. Water Research 37(1), 1-10.

Vuorela, I. \& Aalto, M., 1982. Palaeobotanical investigations at a Neolithic dwelling site in southern Finland, with special reference to Trapa natans. Annales Botanici Fennici 19(2), 81-92.

Weninger, B. \& Jöris, O., 2004. Glacial Radiocarbon Calibration. The CalPal Program. In: Higham, T. et al. (eds.) Radiocarbon and Archaeology. Fourth International Symposium. Oxford, 2002, Oxford University School of Archaeology, Monograph 62, p. 9-15. 